\title{
Differences in Perception and Diction on Two Translations Lelaki Tua dan Laut from Ernest Hemingway's The Old Man and The Sea
}

\author{
Lina Meilinawati Rahayu \\ Universitas Padjadjaran \\ Email: lina.meilinawati@unpad.ac.id
}

\begin{abstract}
Translation of literary work is never simply the business of translating the work in the source language into the target language. Translation is always culture-sensitive, as it also means translating the source culture into the target culture. This study examines two translations of the novel The Old Man and The Sea (1952) by Ernest Hemingway in the Indonesian language. Both are titled Lelaki Tua dan Laut. The earlier was published in 1973 and was translated by Sapardi Djoko Damono, while the latter was translated by Dian Vita Ellyati and was published in 2010. These two translated versions are compared with each other in order to identify differences in perception and diction. Differences in diction further influence the reader's perception. Close examination of the two versions discovers contrasting perception and diction. The study finds that Djoko Damono's translation builds meaning by using Indonesian equivalents to represent the concepts presented in the novel, while Ellyati's builds meaning through description and explanation of said concepts. Djoko Damono's translation attempts to maintain poetic expressions through the use of rhyming words; Ellyati's translation goes for clarity of meaning. Djoko Damono's translation uses extensive vocabulary with specific meanings, while Ellyati's chooses to employ words with more generic meanings. These differences indicate that translation work is never final; it is an ongoing, ever changing process.
\end{abstract}

Keywords: diction, difference in translation, literature in translation, perception, translation

\section{INTRODUCTION}

Translators are like farmers who work on neighbor's farm field while the outcomes belong to the landlord. This imagery proverb is offered by Dryden's Bassnet (1993:146). In the other words, whoever becomes the translator, the writer remains the fame. But actually, without the translators' hard works, a writing will not be well-known in other languages and cultures. In the other words, translators play and position an important role as mouthpiece, intention successor, messenger and connector between one culture and another. A writing could cross time and space for the translators' hard works. Language is a product of a specific culture. Language, therefore reflect the values and norms of the culture. These reflect in its vocabulary and metaphors (Sumardjono, 2007).

Translations on Indonesian literature have been done since years. Chambert-Loir (2009) said that in 1996, for the first time in Nusantara, the reading on Wirataparwa occurred. This was the very first book of several Mahabarata translation projects. It shows that translations activity have existed since long ago, at least more than hundred years ago. This fact is supported by Moriyama (2009) who explained that translation on European 
literature to Sundanese language had been done in $19^{\text {th }}$ century. Printing activity has existed in Sundanese land since 1850. Translations then appeared in second-half of $19^{\text {th }}$ century. Most of the writings were translated based on books from Europe. Kartawinata (1846-1906) is the personage in translation that time. In 1874, Kartawinata positioned as official translator to Dutch East Indies era.

When Indonesian literature was developing, translations became massive. It can be seen in drama development in Indonesia. Translations on drama were quite interesting. In $1950 \mathrm{~s}$, translations on drama were quite frequent. The desire to translate Western drama was getting stronger, for theatre groups appeared in that era did not obtain the wanted scripts. The massive number of plays was the reason why stage actors translated the scripts, for the original scripts did not satisfy them. Sumardjo (1988) said that the need on original play scripts is acquired if there is an effort to "improve" modern theatrical plays in Indonesia. The choice on play scripts translation is considered as the way out, because theatrical performance is not equal to the number of scripts. Even If the play scripts are provided, the quality is far from satisfaction. This explanation shows that translation on literature has an important position.

Translations on fictional works have long been a debate, whether to which the translated works belong, to the original or to the target language. Firmly, Salam (tt) said that translated literary works belong to the target language. Argumentatively, a translated literary work is an independent literary text in its source language. If a novel is translated to Bahasa Indonesia, it becomes part of Indonesian literature. I am in one side to this that a translated literary work is part of the literature of target language, for the language is switched. Some adjustments have been applied to it.

Furthermore, Chamber-Loir explained about the current environment of translated literary works in Indonesia. He said that most of Indonesian translators adhere "formal agreement," which is the action of replacing original text mechanically. Meanwhile, in early development of translation in Indonesia, "dynamic agreement" was used to reorganize the source text in order to produce same effect with different target

Nowadays, there are only few publishers who specialize themselves on translated literary works. However, among those few publishers, we might still have hope to Penerbit Obor Jakarta that consistently translates several literary works which have been reprinted several times. Among those translated literary works, there are works that are translated by different translators. Albert Camus's L'Etranger, for instance, was translated by Apsanti Djokosusanto to Orang Asing. The same book was then translated under the title Sang Pemberontak by Ermelinda. Ones that take most attention are works of Kahlil Gibran. It is recorded that several translators like Iwan Nurdaya, Sugiarta Sriwibawa, Sri Kusdyantinah and Sapardi Djoko Damono have translated his works. Thus, translating works that have been beforehand translated is a prevalence, for a translated literary work is not a final result. In this paper I am going to focus on observing two translated literary works from The Old Man and The Sea, one that is translated by Sapardi Djoko Darmono (later is abbreviated as SDD) and the other by Dian Vita Ellyato (later is abbreviated as DVE).

The reason on comparing these to translations is because both of them are different in terms of expressions. One that is distinct is in perception, diction, and sentencing. Both research objects are examined to obtain the sight-seen differences especially in terms of perception and diction. This research will be developed based on both following questions: (1) What are the differences in perception and diction in both translations? (2) How do those differences influence the translations?

\section{Data Source}

This research uses two translated literary works as its objects:

1. Lelaki Tua dan Laut. trans. Sapardi Djoko Damono, 1973.

2. Lelaki Tua dan Laut. trans. Dian Vita Ellyati, 2010.

\section{THEORETICAL BASIS}

Translation is a process of transformation. As said by Walter Benjamin in Bassnett (1993:151) that 
claimed translation developed as a transformative process. His essay is later found by translation critics in 1980s and has become one significant text of postmodern translation. Lindsay (2006) quoted Venuti, "Translation, in other word, inevitably performs a work of domestication."

Newmark (1988) said that there are eight methods in translation. Among all those eight methods, Newmark halves them to either it is closer to the source language (word-for-word translation, literal translation, faithful translation, semantic translation) or closer to the target language (adaptation, free translation, idiomatic translation, communicative translation). An easyto-read translated work is certainly closer to the source language. If a translator borrows a language as the vehicle, it means s/he borrows other required aspects (expression, diction, language style, and etc.) in the borrowed language. The same way goes to argument stated by Nida (1964) who defined translation as reproductive process of equivalent word to the target language, in term of meaning and structure. The reproduction is natural translation that has the exact same message to the target language.

Related to perception and diction which are the research object, I shall use the definition of persepsi from KBBI (2008:1061), “(1) tanggapan (penerimaan) langsung dari sesuatu; serapan; (2) proses seseorang mengetahui beberapa hal melalui pancaindranya. Ini dijadikan sebagai landasan karena ada perbedaan persepsi (tanggapan) dari kedua penerjemah atas sesuatu (jenis ikan, nama makanan, panggilan, dan lain-lain)". The differences of perception occurred because of diction.

Diction is the act of choosing the correct word which meaningfully matches the expression to obtain certain effect (KBBI, 2008:328). Thus, differences of diction can cause a different developed effect in readers' mind. Speaking of diction, it cannot be denied that it is closely related to: denotative and connotative words, (1) words that have the same meaning; (2) common and specified word; (3) words that change meaning; (4) words that have similar spelling; (5) selfcreated words; (6) idioms; (7) short and long words (Hamid, 1996). In using the words, several factors that are out of literary league. Those factors are closely related to the diction, for words serve as idea expression. Based on that, to simply express an idea, the accuracy of the chosen word is needed, the compatibility of words and talking situation, and reader condition.

Based on those explanations, it shows that differences in diction influence the meaning nuance. So that, research on diction differences on translated words from two distinct translators becomes significant.

There are numbers of research on translation conducted in recent year, one of which is "Nothing left to learn: Translation and the Groundhog Day of bureaucracy" by Michal Izak (2016), showing that a translator is a creative artist. This research critically explores translators' experience in translation process. A translator should create dialogical climate between source language and target language. Leticia ÁlvarezRecio's work (2016) entitled "Spanish chivalric romances in English translation Anthony Munday's Palmendos (1589)" points out that Anthony Munday is an important figure in book trade in England. He proposes valuable information on the importance of the congruity between a translation work and its target language. Translator's decisions on ideology and aesthetic is also a crucial consideration which affects a translation work. An article entitled "News translation: global or cosmopolitan connections?" by Esperanza Bielsa (2015) discusses three important matters, which are: social theory, translation study, and media study on news translation. An interesting article on Quran translation entitled "Grammar-Related Semantic Losses in the Translation of the Holy Quran, with Special Reference to Surah Al A'araf (The Heights)" by Noureldin Mohamed Abdelaal and Sabariah Md Rashid (2016) illustrates how translating Quran is a challenging task. However, this condition is inevitable and even imperative since a large number of Muslims do not understand Arabic. Various translations of Quran are available today. According to this article, the loss in those translation works relies heavily on the grammar aspects due to the differences between the source text and the target text. The incongruity of grammatical aspect leads to semantic (meaning) 
differences which relates to connotative meanings as well. Appropriate translation study is imperative to minimize these disadvantages.

Other than that, research on translation is "Translating social sciences into Arabic today as the case of Pierre Bourdieu" (2015). Through the example of the Arabic translations of Pierre Bourdieu, this article analyses the conditions of the introduction and reception of a sociological thought of French origin in the contemporary Arab intellectual field and, more generally, those of the international circulation of ideas in a postcolonial context. Scoville's work (2015) entitled "Reconsidering Nahdawi Translation: bringing Pushkin to Palestine" point out that Translation occupies a central position in any narrative of the Arabic literary renaissance, or nahdah, of the nineteenth century. The vast majority of these translations, however, have been discounted as less than literary because of the freedoms that they took in altering the source texts as they translated. An article entitled "Translation and the world of the text: on the translation of the word hijab in the Qur'an" by Elmarsafy (2015) The article falls into two parts, the first presenting a theoretical exposition of the stakes involved in these translations, while the second traces the operation of the word hijab in several English translations of the Qur'an. We argue that, in the Qur'an, the word hijab demarcates the place that enables communication between the divine and the human.

Then, there are three more articles about translation is "Language and the national allegory: translating Peter Temple's The Broken Shore and Truth into French" (2016) by West-Sooby about Language plays a key role in the crime novels of Peter Temple, where it serves both as a means of constructing a distinctive Australian identity and as a vehicle for expressing Temple's critique of Australian society and its ills. A close comparative reading of his two landmark novels, The Broken Shore and Truth, and their French translations highlights the significance of their linguistic features and the challenges they pose to translators. Barker's work (2016) entitled The prefigurative politics of translation in place-based movements of protest". Last, research crtitically entitled "French in Springfield: a variationist analysis of the translation of first-person singular future actions in the Quebec and French dubbings of The Simpsons" about A variationist analysis of the different solutions along such variables as sex, age, social class, and level of education reveals some emerging but unstable patterns. Overall, the study contends that the variability observed can be perceived both as a style-shifting phenomenon and as an ideological posture taken by translators. The theoretical and practical implications of the findings are discussed.

\section{FINDINGS AND DISCUSSION}

Translation expert, I. Richards, said that translation is perhaps a complex occurrence as the result of universe evolution. However, that occurrence makes a big influence to humanity. Readers who don't comprehend the source language will be benefited by the works of translation. Translators serve as a bridge to enter the other world. In this case, translator opens the way to understand and comprehend literature diversity in the world. As explained, the translated works are not final-never ending process. Finally, there is still a possibility for the next translators to translate the exact same works. The two translated Lelaki Tua dan Laut by Ernest Hemingway are distinct in a long period of time. SDD's translated work was published in 1973, meanwhile DVE's was in 2007-34 years distinct. Thus, SDD's work has been known or read by readers for so long. It cannot be denied that DVE might have read SDD's work before translating.

SDD's and DVE's works agree on script quantity, it means that both do not add and reduce any paragraph. Almost no paragraph is missing. Thus, the focus on this research is how both translators juxtapose all aspects from the source to the target language. After a deep reading on both works, significant differences are obtained in terms of perception and diction from both translators. Differences of perception are differences on point of views towards the way in translating to the target language. This is later going to be the focus of research. 


\section{Differences between Both of Translation Works}

\section{A. Different Perception between Both of Translation Works}

Discussion of this journal would be started from the first paragraph, which is the opening for both of translation works. Analyzing this paragraph becomes significant, because it serves as a starting point to examine following translation results. It can be used to find out what language styles is going to be employed in further translation works. Presented below is quotation from the first paragraph by the two translators. the Gulf of Mexico and heads northeast along the coastline from North America to Foundland, and turns east accross the Atlantic Ocean to the coast of British Isles. This fairly lengthy description is intended to explain as clearly as possible to readers where the event takes place.

Hemingway -in The Old Man and The Seadoes not particularly give a clear explanation about where the event takes place, he uses "Gulf Stream" instead. DVE possibly intends to provide some insight for readers regarding the setting of this story; thus, she leaves several footnotes. It can be beneficial, on one hand, because the readers

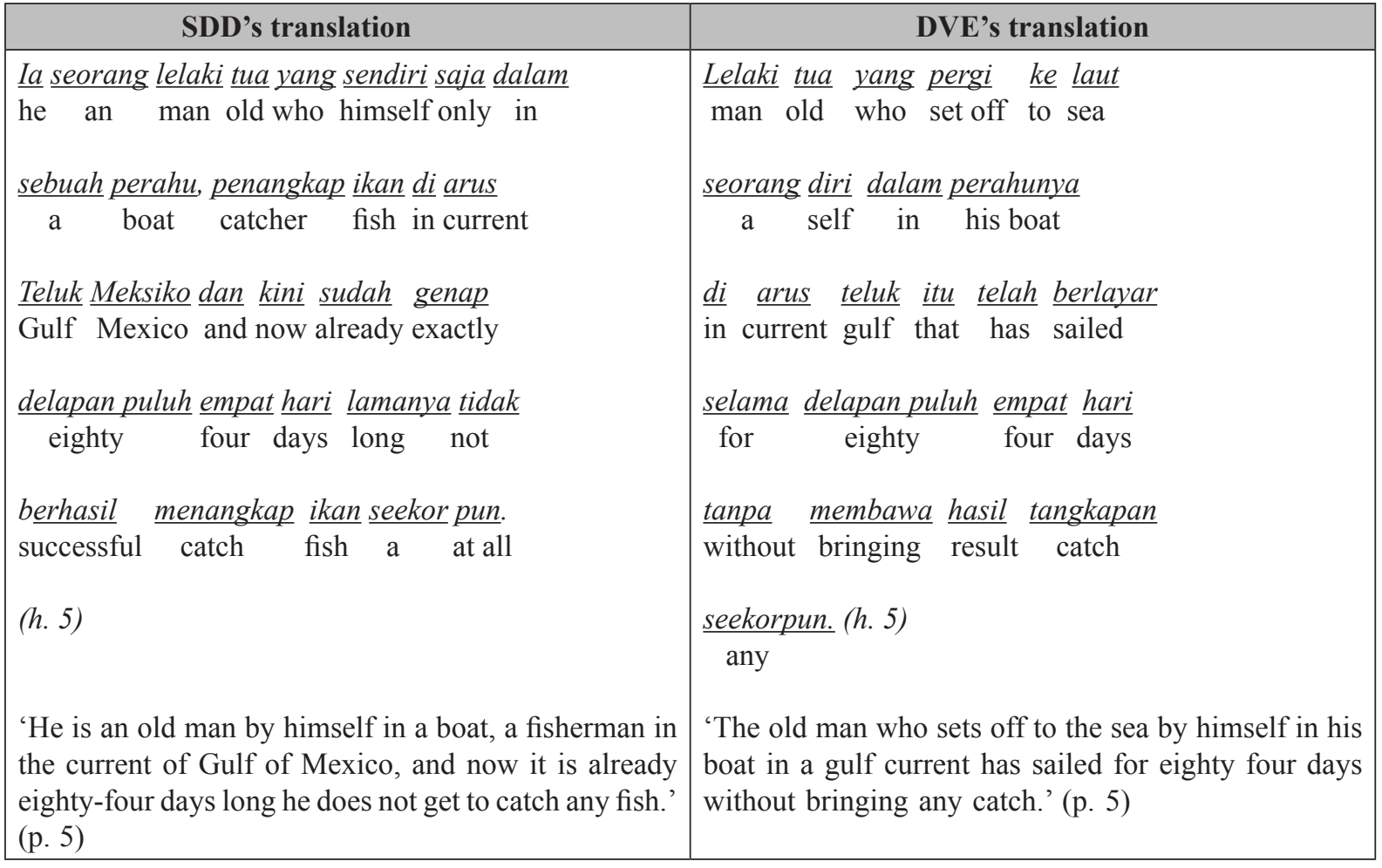

The quotations above are the first paragraph of both translation works. Since the beginning, they already show different way and style in translating the text. Both of them explain the same thing about a man who has sailed for eighty four days, but still cannot catch any fish. However, the two translators have different perceptions in describing the place. SDD straightforwardly translates the place as Gulf of Mexico, while VE only mentions it as a Gulf. Then, VE adds a footnote to make clear about what she means with the Gulf. In the footnote, the Gulf is defined as the warm current that appears in might receive new knowledge. On the other hand, the footnotes interfere with reading process, since people have to flip through pages to read them. In DVE's translation, footnote is also used to explain common knowledge, like " 1 pound $=0.4536 \mathrm{~kg}$ ", yet she does not add a footnote for unfamiliar terms, like "Hatuey beer".

In another part, DVE adds a footnote for the term "Que ya" (p. 18), defined as omong kosong 'nonsense', while SDD leaves it untranslated. If "que ya" has an equivalent meaning with omong kosong 'nonsense', then a footnote is not 
particularly important, because the meaning stays intact. Translating it as "nonsense" would be sufficient.

It happens as well for names and types of fish. For instance, sekumpulan bonito 'a school of bonito' is explained in a footnote as Kenyar, or tuna; and Sarda, as a type of tuna with blue strips on its back from mackerel family. This additional definition merely provides information (insight) to the readers. In the DVE's translation, rumput laut Sargasso 'Sargassum seaweeds' is explained as Ganggang coklat Sargassum 'Sargassum brown algae'. In this case, the translation and the footnotes do not necessarily produce a clearer meaning or form for the nouns.

Footnotes have a function to show or to confirm evidences for all statements and information regarding something that actually needs further explanation. In a literary translation, footnotes can be useful if there is no equivalent terms available, or the terms are distinctive, related to the culture of source language. However, if the cases are like aforementioned examples in DVE's translation, footnotes would be considered an interference for readers' convenience. Differences in way of translating will be followed by differences of perception and diction as analysis materials.

Different perception occurs in translating nouns and expressions, as shown below in a quotation about a type of food.

In the quotation above, SDD uses karung gandum 'wheat sack', while DVE uses karung tepung 'flour sack'. This different perception is not going to misguide the readers, because wheat and flour share a similarity, which are basic ingredients of bread, and they are basically flour. However, SDD chooses to be more specific by pointing out the flour's type (wheat), while DVE chooses to play safe by using a more general word (flour). Still from the same quotation, both of them describe filth in different way. SDD's translation is [...]nampak seperti panji-panji tanda takluk abadi 'it looks like a banner of eternal vanquish', while DVE's is [...]nampak seperti bendera kalah perang 'it looks like a flag of defeat'. Both of them have the same meaning, but create different tones. Using the phrase of takluk abadi takluk abadi 'eternal vanquish' means the chance of victory is long gone -the vanquish is eternal (permanent)--. Meanwhile, DVE chooses a more general phrase, that is kalah perang 'defeat'.

It has been explained that SDD's translation tends to choose specific words to "assert" the meaning. The examples of this case are also found in following translation, as presented in quotations below.

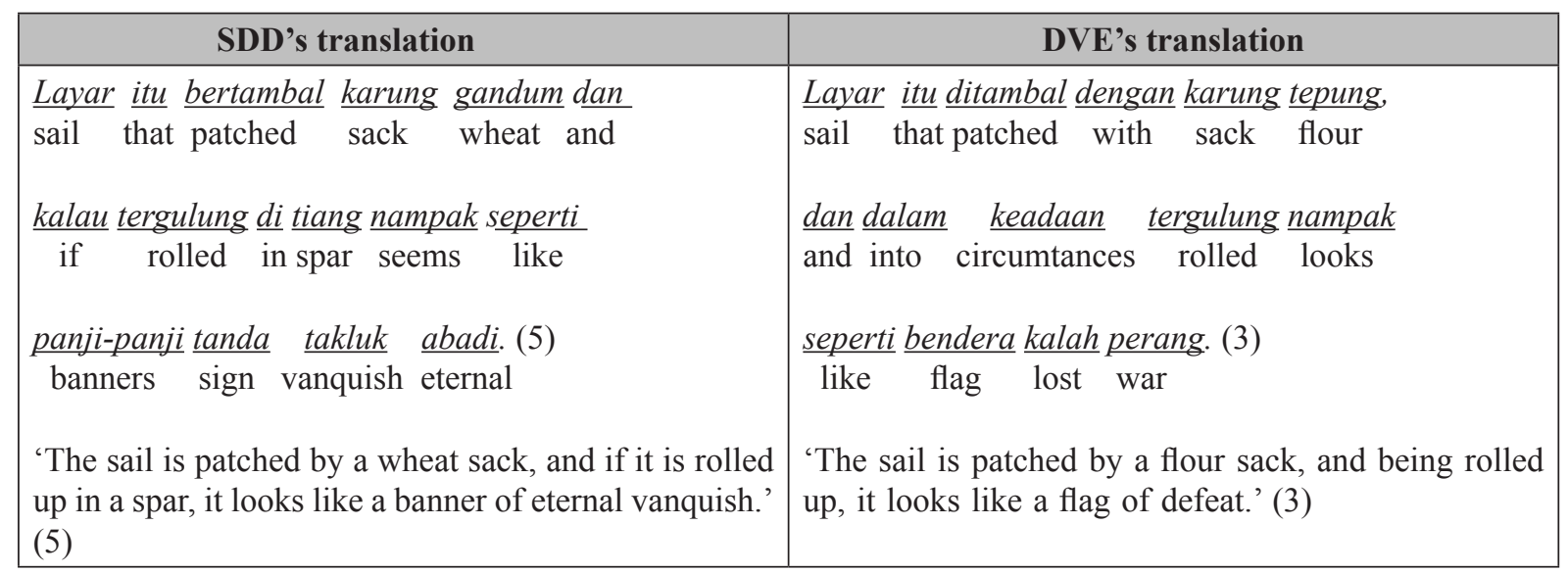




\begin{tabular}{|c|c|}
\hline SDD's translation & DVE's translation \\
\hline$\frac{\text { Sudah }}{\text { already I explore }} \frac{\text { kujelajahi }}{\text { resevoirs }} \frac{\text { lubuk-lubuk }}{\text { that }} \frac{\text { itu }}{\text { for }}$ & $\frac{\text { Aku }}{\mathrm{I}} \frac{\text { bekerja }}{\text { work }} \frac{\text { pada }}{\text { in }} \frac{\text { kedalaman }}{\text { depth }}$ which $\frac{\text { terlalu }}{\text { too }}$ \\
\hline$\frac{\text { seminggu }}{\text { a week }} \frac{\text { dan }}{\text { and the result naught he thinks }}$ & $\underset{\text { far }}{\text { jauh }} \frac{\text { selama }}{\text { for }} \frac{\text { seminggu }}{\text { a week }} \frac{\text { tanpa }}{\text { without }} \frac{\text { menghasilkan }}{\text { resulting }}$ \\
\hline (h. 26) & $\begin{array}{l}\text { apapun, timbangnya. }(h .27) \\
\text { anything he considers }\end{array}$ \\
\hline $\begin{array}{l}\text { 'I've been exploring the reservoirs for a week and the } \\
\text { result is naught, he thinks.' (p.26) }\end{array}$ & $\begin{array}{l}\text { 'I've been working way far too deep for a week without } \\
\text { resulting anything, he considers.' (p. 27) }\end{array}$ \\
\hline
\end{tabular}

SDD chooses the word nihil 'naught', which means nothing at all, while DVE uses tanpa menghasilkan apapun 'without resulting anything'. Both of them have the same meaning. SDD attempts to find the equivalent word, while DVE elaborates the definition. It can be said as though DVE's translation is explanation of SDD's.

The quotation below would confirm the argument before.

\begin{tabular}{|c|c|}
\hline SDD's translation & DVE's translation \\
\hline Tampak olehnya rumput kuning tersangkut & Nampak rumput laut berwarna kuning pada \\
\hline Appear by him seaweed yellow caught & Seen seaweed color yellow on \\
\hline pada talinya dan lelaki tua itu senang & tali pancing, tetapi lelaki tua itu tahu \\
\hline on his rope and man old that pleased & rope fish but man old that know \\
\hline sebab rumput $\underline{\text { itu }}$ ikut memberati & bahwa tumbuhan itu hanya akan menambah \\
\hline$\overline{\text { because seaweed that also weighting }}$ & that plants that only will add \\
\hline $\begin{array}{l}\text { talinya. } \\
\text { his rope seaweed gulf }\end{array}$ & $\frac{\text { beban }}{\text { load }} \frac{\text { tarikan }}{\text { pull }} \frac{\text { and }}{\text { and }}$ exastru $\frac{\text { membuatnya }}{\text { make him }}$ \\
\hline memancarkan cahaya warna-warni pada & senang. Ia adalah rumput laut teluk \\
\hline radiate lights colorful at & pleased he is seaweed gulf \\
\hline$\frac{\text { malam hari. }}{\text { night }}$ (h.51) & $\frac{\text { yang }}{\text { which }} \frac{\text { menghasilkan }}{\text { produce }} \frac{\text { banyak }}{\text { much }} \underset{\text { phosforesensi }}{\text { phorence }}$ \\
\hline & $\underset{\text { at }}{\text { pada }} \frac{\text { malam hari. }}{\text { night }}$ (h.52) \\
\hline $\begin{array}{l}\text { 'It appears to him the yellow seaweeds are caught } \\
\text { by his rope and the old man is pleased, because } \\
\text { the seaweeds are weighting his rope. The yellow } \\
\text { seaweeds of the Gulf radiate colorful lights at night.' } \\
\text { (p. 51) }\end{array}$ & $\begin{array}{l}\text { 'It can be seen yellow seaweeds are on the rope, } \\
\text { but the old man knows that the plants will only } \\
\text { add a pull force and it makes him pleased instead. } \\
\text { They are seaweeds of the gulf that create much } \\
\text { phosphorescence at night.' (h.52) }\end{array}$ \\
\hline
\end{tabular}


SDD uses the expression of rumput itu memberati talinya 'the seaweeds are weighting his rope', while DVE picks a different choice, tumbuhan itu hanya akan menambah beban tarikan 'the plants will only add a pull force'. As argued previously, SDD tends to choose specific word (seaweeds), while DVE uses a more general one (plants). In the last sentence, SDD uses cahaya warna-warni 'colorful lights' and DVE chooses fosforesensi 'phosphorence', which expresses an ability for something to radiate. This uncommon term, however, is not equipped with a footnote. Different perception in expressing something will be affirmed by three quotations below:

\begin{tabular}{|c|c|c|}
\hline & SDD's translation & DVE's translation \\
\hline A & $\begin{array}{l}\frac{\text { Sebelum }}{\text { Before }} \frac{\text { pancingnya hook }}{\text { his hoongena }} \frac{\text { lelaki }}{\text { man }} \\
\frac{\text { tua }}{\text { old that }} \frac{\text { itu }}{\text { menekan }} \\
\frac{\text { pampai }}{\text { hat }} \frac{\text { tope }}{\text { until to }} \frac{\text { pandannya }}{\text { his straw }} \\
\frac{\text { mengakibatkan }}{\text { resulting to }} \frac{\text { sedikit }}{\text { a little }} \frac{\text { lecet. }}{\text { scratch }}(h .42) \\
\text { 'Before his hook catches a fish, the old man } \\
\text { presses his straw hat to his forehead that results to } \\
\text { a little scratch.' }\end{array}$ & 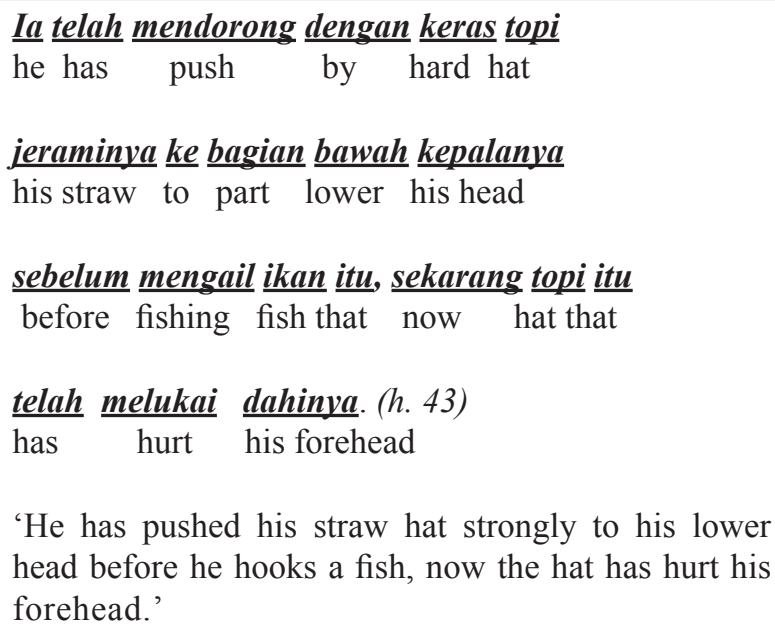 \\
\hline B & 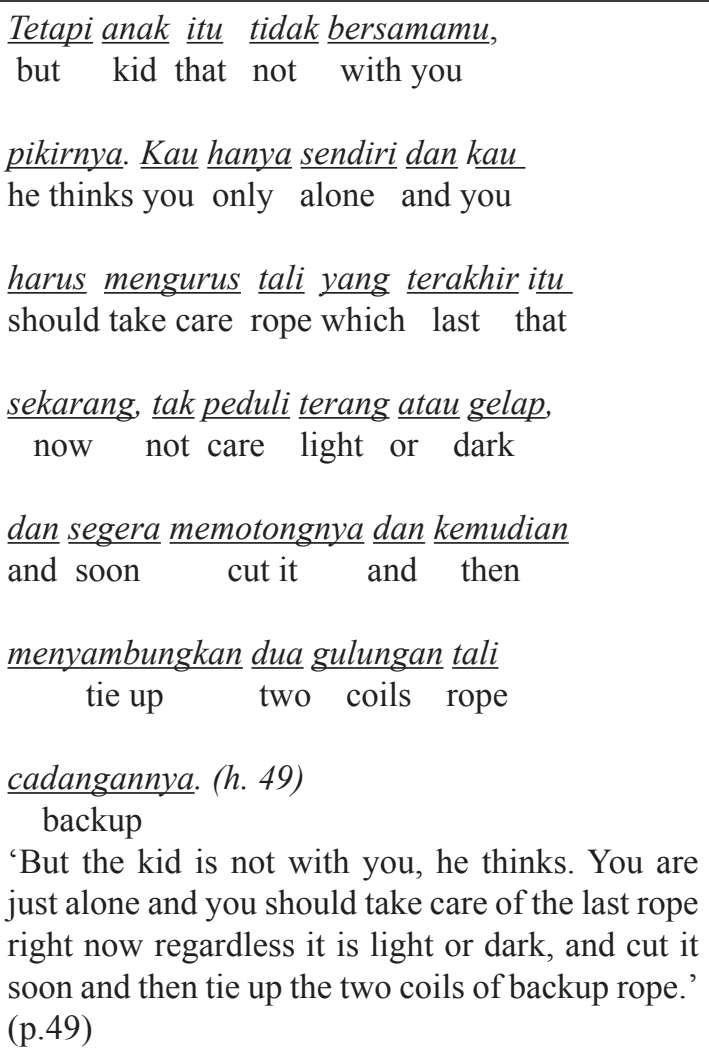 & 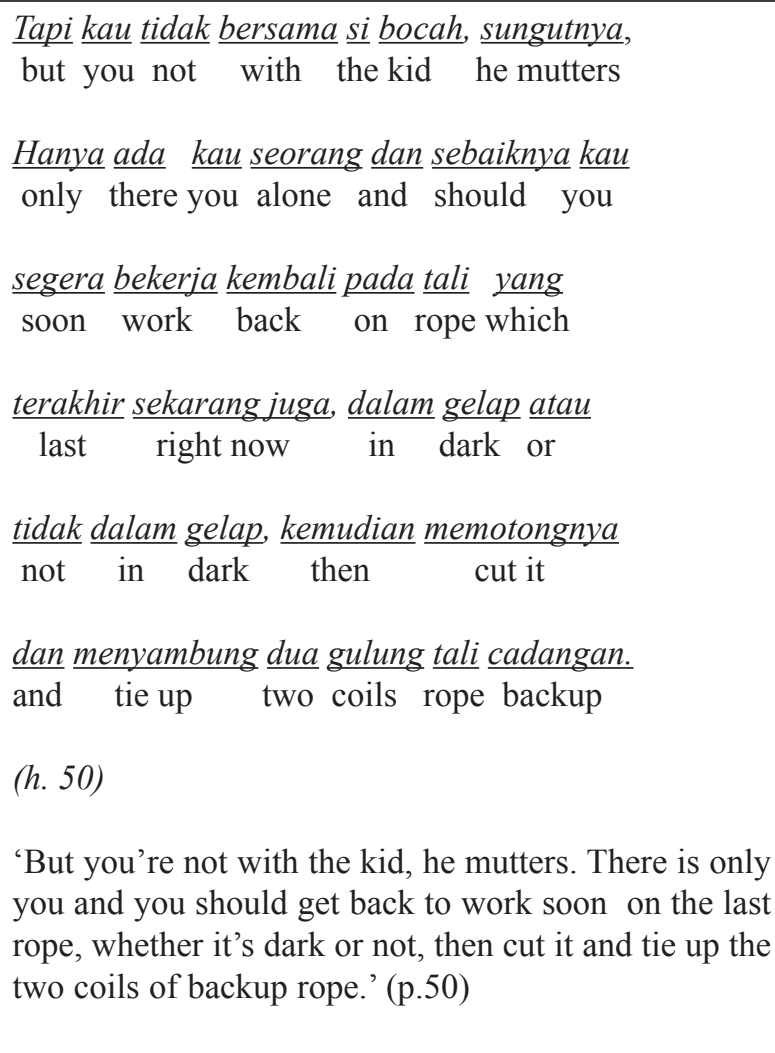 \\
\hline
\end{tabular}




\begin{tabular}{|c|c|c|}
\hline & SDD's trans & DVE's translation \\
\hline c & 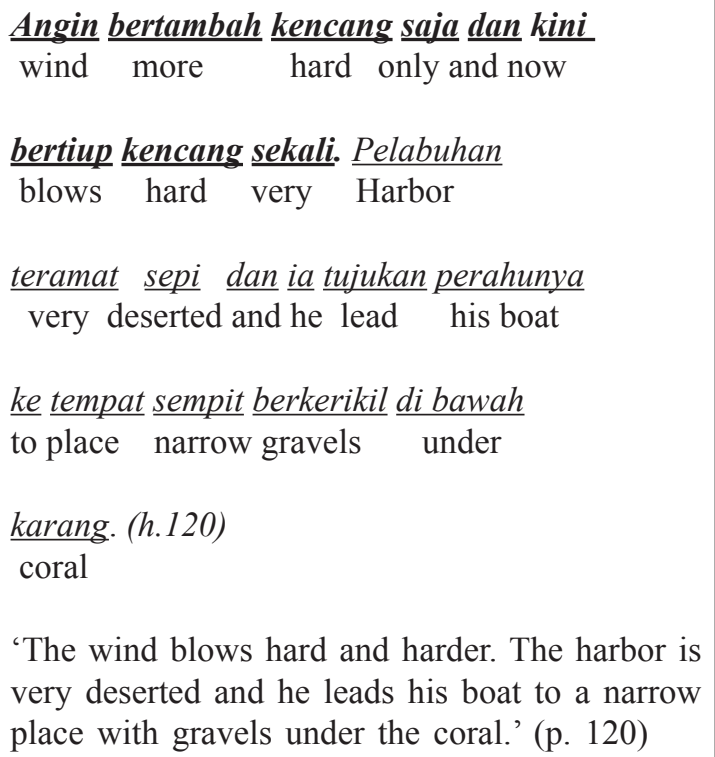 & $\begin{array}{l}\frac{\text { Angin }}{\text { wind }} \frac{\text { bertiup }}{\text { blows }} \frac{\text { dengan }}{\text { by }} \frac{\text { teratur }}{\text { regular and }} \frac{\text { dan }}{\text { hard }} \\
\frac{\text { dan }}{\text { and he }} \frac{\text { ia }}{\text { he }} \frac{\text { berlayar }}{\text { sails }} \frac{\text { ke atas }}{\text { up }} \frac{\text { menuju }}{\text { to }} \frac{\text { bidang } \frac{\text { kecil }}{\text { area small }}}{\frac{\text { dari }}{\text { of }} \frac{\text { sirap }}{\text { shingles }} \frac{\text { di bawah }}{\text { under }} \frac{\text { bebatuan }}{\text { rocks }}(h .125)}\end{array}$ \\
\hline
\end{tabular}

Three of quotations above confirms what has been previously argued that the translators have different perceptions. Sentence (a) explains a situation when the old man presses his hat 'till it hurts his forehead. SDD uses the sentence sampai ke dahi dan mengakibatkan sedikit lecet 'to his forehead that causes a bit scratch', while DVE chooses to express it by using the sentence sekarang topi itu telah melukai dahinya 'now the hat hurts his forehead'. Lecet 'scratch' is a more spesific word than luka 'hurt'. The same expression is also shown in quotation (b). SDD writes tak peduli terang atau gelap 'regardless it is light or dark', while DVE writes dalam gelap atau tidak dalam gelap 'whether it's dark or not'. SDD uses opposite meaning by choosing antonyms (light and dark). DVE does not use antonym, but negation of the word instead (dark or not). In quotation (c) similar thing happens. SDD describes the wind that blows harder by using the sentence angin bertambah kencang saja dan kini bertiup kencang sekali "the wind blows hard and harder". This circumstance explains from kencang 'blowing hard' state to kencang sekali 'harder' state. While DVE expresses it by using the sentence Angin bertiup dengan teratur dan kencang 'the wind blows in a regular and hard manner'. It shows a different perception between the two translators in describing the blowing wind. The phrase of kencang 'hard' and kencang sekali 'harder' describes similar situations (hard and harder), while teratur 'regular' and kencang 'hard' shows different situations and different perception of meaning in readers' mind. It could be from blowing hard to regular, or vice versa.

The discussion before proves that translation from two different persons produces different perceptions: translator's perception on translated words, and reader's perception on translated works. Perception is also associated with words, group of words, and the wording (or sentencing) occupied by the translator. SDD's translation generally uses specific words combined with suitable idiomatic expression leading to a deeper sense of perception. DVE's translation uses more common words with additional descriptions to explain things clearer and more detailed.

\section{B. The Differences of Diction from The SDD and DVE's Translations.}

Diction or choice of words has an important role in creating nuances of meaning to express an idea. Writing requires the accuracy of words to express an idea; the suitability between words and context helps the reader to understand the idea being delivered. The accuracy of diction is able to build certain nuances in the readers' mind especially in the translated works in which the cultural contexts may be completely strange to them. Every translator certainly attempts to 
find the most accurate words to make the readers understand the translated works the way they do to be able to explore the treasure of literature from other nations and cultures. The results from the analysis of diction on both translations are as follows.

\section{The Translation of Pronouns}

Personal pronouns have different nuances for each nation. Acceptable pronouns in one culture might not be acceptable and equivalent to another. For example, calling a son/daughter in law with the words "son/daughter in law" is prevalent in Indian culture. However, this is not acceptable in Indonesian culture. Indonesian does not address a son/daughter in law as menantu 'son/daughter in law' in daily conversation because they regard the in laws to be the same as their own child. The word "you" in English refers to neutral addressing words. This, however, is not the case with Indonesian culture. Further explanation on personal pronouns in both of the translations will be discussed below. translates it into bocah 'kid'. Here, SDD chooses specific words by mentioning the sex (laki-laki, an Indonesian word for male). DVE, on the other hand, chooses to translate it to the word bocah 'kid' which could be a boy or a girl. The differences of pronouns translation also results to different effect on reader's mind.

Next in the excerpt (b) the differences of pronouns translation can be found in addressing an older person (male). English pronoun 'you' has neutral meaning. That is, the expression can be said to anyone regardless the status or the age. SDD translates it to various expressions equal to 'you'. He translates 'you' to 'kau' as shown in the excerpt (b) above. Sometimes he also uses the term sobat tua 'old friend' as in

"Semoga kau beruntung, sobat tua." (h.24) hope you lucky old friens 'I hope you are lucky, old friend.' (p. 24)

Unlike him, DVE chooses word or expression commonly used in the Indonesian culture. As can be seen in the excerpt (b) above, DVE translate the

\begin{tabular}{|c|c|c|}
\hline & SDD's translation & DVE's translation \\
\hline $\mathrm{a}$ & 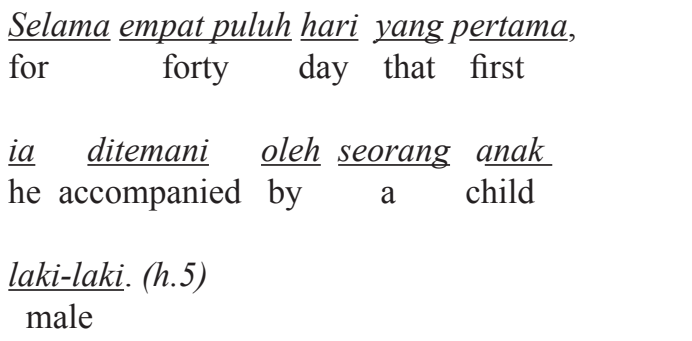 & $\begin{array}{l}\frac{\text { Selama }}{\text { for }} \frac{\text { empat puluh }}{\text { forty }} \frac{\text { hari }}{\text { day }} \frac{\text { pertama }}{\text { first }} \frac{\text { seorang }}{\text { a }} \\
\frac{\text { bocah }}{\text { kid accompanied him }} \text { (h. 3) }\end{array}$ \\
\hline & $\begin{array}{l}\text { 'For the forty first days, he was accompanied by } \\
\text { a boy' (p.5) }\end{array}$ & 'For the first forty days, a kid accompanied him.' (p.3) \\
\hline $\mathrm{b}$ & $\begin{array}{l}\text { "Apa } \frac{\text { yang }}{\text { what }} \frac{\text { akan }}{\text { that }} \frac{\text { kaumakan?" }}{\text { you eat? }} \frac{\text { tanya }}{\text { ask }} \\
\frac{\text { anak }}{\text { kid }} \frac{\text { itu. }}{\text { that }}(h .12)\end{array}$ & $\begin{array}{l}\text { "Apa yang } \frac{\text { Bapak }}{\text { what that }} \frac{\text { punya }}{\text { father }} \frac{\text { untuk }}{\text { have }} \frac{\text { dimakan?" }}{\text { be eaten? }} \\
\frac{\text { si }}{\text { the }} \frac{\text { Bocah }}{\text { kid }} \frac{\text { bertanya. }}{\text { ask }} \text { (h. 11) }\end{array}$ \\
\hline & $\begin{array}{l}\text { 'What will you eat?" asked the boy.' } \\
\text { (p. 12) }\end{array}$ & $\begin{array}{l}\text { "'What do you Sir have that can be eaten?" the kid } \\
\text { asked.' (p.11) }\end{array}$ \\
\hline
\end{tabular}

In the excerpt (a) there is difference of diction in translating the word "boy". SDD chooses the words anak laki-laki 'boy', while DVE word kau 'you' into Pak 'sir' (abbreviated form of Bapak 'mister'), so does the term sobat tua 'old friend' that still uses the word Pak 'sir', as in 


\author{
"Semoga beruntung, Pak." (h. 23) \\ hope lucky sir \\ 'Good luck, sir.' (p. 23)
}

The word 'Pak' shows hierarchy in term of age and distance. However, in Indonesian culture this expression is commonly used to address someone whose age gap is significant, or to address a respected person.

\section{The Translation of Kinds of Food}

Other differences from both of the translations can also be found in term of food as shown in the excerpts below.

\begin{tabular}{|c|c|c|}
\hline & SDD's translation & DVE's translation \\
\hline $\mathrm{a}$ & $\begin{array}{l}\frac{\text { Kedelai }}{\text { soybean and rice }} \frac{\text { dan }}{\text { risi }} \text {, pisang goreng } \frac{\text { dan }}{\text { bana }} \text { and } \frac{\text { daging }}{\text { meat }} \\
\begin{array}{l}\text { rebus. } \\
\text { boiled }\end{array} \\
\text { 'Soybean and rice, fried banana, and boiled meat/ } \\
\text { stew.' (p. 16) }\end{array}$ & $\begin{array}{l}\frac{\text { Kacang polong }}{\text { peas }} \frac{\text { dan }}{\text { and rice }} \frac{\text { nasi, }}{\text { bisang goreng, }} \text { bana fry and } \\
\left.\frac{\text { sayuran }}{\text { vegetable boiled }} \frac{\text { rebus. }}{\text { boil }} \text { ( } 14\right) \\
\text { 'Peas and rice, friend banana, and boiled vegetables.' } \\
\text { (p. 14) }\end{array}$ \\
\hline $\mathrm{b}$ & 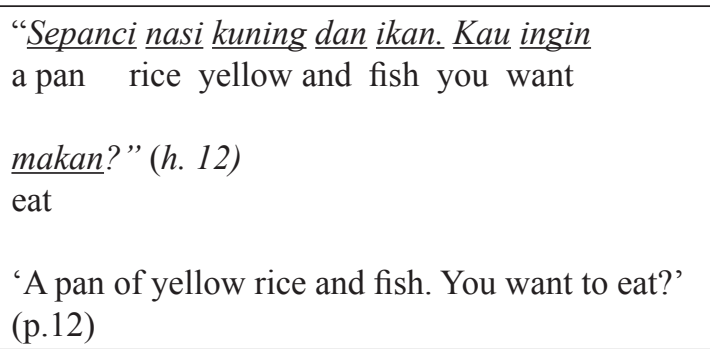 & 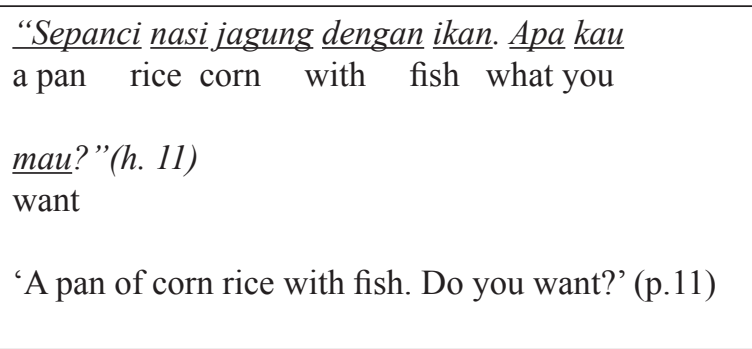 \\
\hline
\end{tabular}

Different diction in translating kinds of food can be seen from the excerpts above. First, SDD uses the word 'kedelai' (soybean) while DVE chooses kacang polong 'peas'. Both still belong to varieties of beans, but the nuances created by each diction are different. Kedelai 'soybean' is a type of beans that is commonly known in Indonesian culture, while kacang polong 'peas' is not popular consumption of the society. Second, SDD translates daging rebus 'stew/boiled meat' while DVE uses sayuran rebus 'boiled vegetables'. Both of the foods are quite different even though they share the same process of cooking. And third, SDD mentions nasi kuning 'yellow rice', while DVE chooses nasi jagung 'corn rice'. Again, nasi kuning is more common to Indonesian culture, while nasi jagung even though it is also widely known, is not as common as nasi kuning. Of the three differences in translating the food, the most striking one is the difference between daging 'meat' and sayuran 'vegetables'. This difference is difficult to explain because it is clear that both are two different kinds of food.

\section{The Translation of Terms and Sentencing}

As being discussed before, DVE has tendency to describe than to find suitable and equivalent words, making her translation to be slightly longer. Here we will be discussing how both translators deliver ideas in the sentences. 


\begin{tabular}{|c|c|c|}
\hline & & $\mathbf{E}$ \\
\hline $\mathrm{a}$ & $\begin{array}{l}\frac{\text { Seluruh }}{\text { whole }} \frac{\text { tubuhnya }}{\text { his body }} \frac{\text { nampak }}{\text { appear }} \frac{\text { tua }}{\text { old }} \frac{\text { kecuali }}{\text { except }} \\
\frac{\text { sepasang }}{\text { a pair of his eyes that }} \frac{\text { yang }}{\text { its colors }} \frac{\text { warnanya }}{\text { like }} \\
\frac{\text { laut }}{\text { seata }} \frac{\text { serah }}{\text { and bright }} \frac{\text { dan }}{\text { and no }} \frac{\text { tak }}{\text { nenal }} \frac{\text { ken }}{\text { give up }} \\
\text { (h. 6) }\end{array}$ & $\begin{array}{l}\frac{\text { Segala }}{\text { all sesuatu }} \text { something on } \frac{\text { pada }}{\text { himself }} \frac{\text { dinenggambarkan }}{\text { describe }} \\
\frac{\text { keuzuran }}{\text { senile }} \frac{\text { selain }}{\text { except a pair of his eyes }} \frac{\text { sepang }}{\text { matanya }} \frac{\text { Kedua }}{\text { both }} \frac{\text { mata }}{\text { yes }} \\
\frac{\text { itu }}{\text { that }} \frac{\text { berwarna }}{\text { color }} \frac{\text { serupa }}{\text { similar }} \frac{\text { laut }}{\text { sea }} \frac{\text { dan }}{\text { and }} \frac{\text { menyiratkan }}{\text { imply }} \\
\frac{\text { keriangan }}{\text { joy }} \frac{\text { serta }}{\text { and }} \frac{\text { semangat }}{\text { spirit }} \frac{\text { yang }}{\text { that }} \frac{\text { tak }}{\text { no }} \frac{\text { bisa }}{\text { can }} \\
\frac{\text { dipadamkan. (h. 4) }}{\text { turned off }} \\
\text { 'Everything on him showed his weakness except for } \\
\text { a pair of his eyes. Those eyes whose color resembled } \\
\text { the sea and implied unstoppable joy and spirit.' (p.4) }\end{array}$ \\
\hline b & $\begin{array}{l}\frac{\text { Lelaki }}{\text { man }} \frac{\text { tua }}{\text { old that }} \frac{\text { itu }}{\text { stare at him }} \frac{\text { dengan }}{\text { with }} \frac{\text { mata }}{\text { eyes }} \\
\frac{\text { yang }}{\text { that }} \frac{\text { masak }}{\text { ripe }} \frac{\text { oleh }}{\text { by }} \frac{\text { terik }}{\text { blaze }} \frac{\text { matahari, }}{\text { sun }} \frac{\text { yang }}{\text { that }} \\
\frac{\text { yakin }}{\text { sure and fun }} \frac{\text { dan }}{\text { funh }} \frac{\text { rasa sayang. }}{\text { love }} \text { (h.9) } \\
\text { 'The old man stared at him with his sunburned, } \\
\text { confident loving eyes.' (p.9) }\end{array}$ & $\begin{array}{l}\frac{\text { Lelaki }}{\text { man }} \frac{\text { itu }}{\text { that }} \frac{\text { memandanginya }}{\text { looking at him }} \frac{\text { dengan }}{\text { with }} \frac{\text { bola }}{\text { ball }} \frac{\text { mata }}{\text { eye }} \\
\frac{\text { yang }}{\text { that }} \frac{\text { terbakar }}{\text { burnt }} \frac{\text { matahari }}{\text { sun }} \frac{\text { menyiratkan }}{\text { imply }} \frac{\text { hati }}{\text { heart }} \\
\frac{\text { yang penuh }}{\text { that full }} \frac{\text { rasa sayang }}{\text { love }} \frac{\text { dan }}{\text { and }} \frac{\text { percaya diri. }}{\text { confident }} \text { (h.7) } \\
\text { 'That man looked at him with his sunburned eyes, } \\
\text { implying a heart full of love and confident.' (p.7) }\end{array}$ \\
\hline $\mathrm{c}$ & 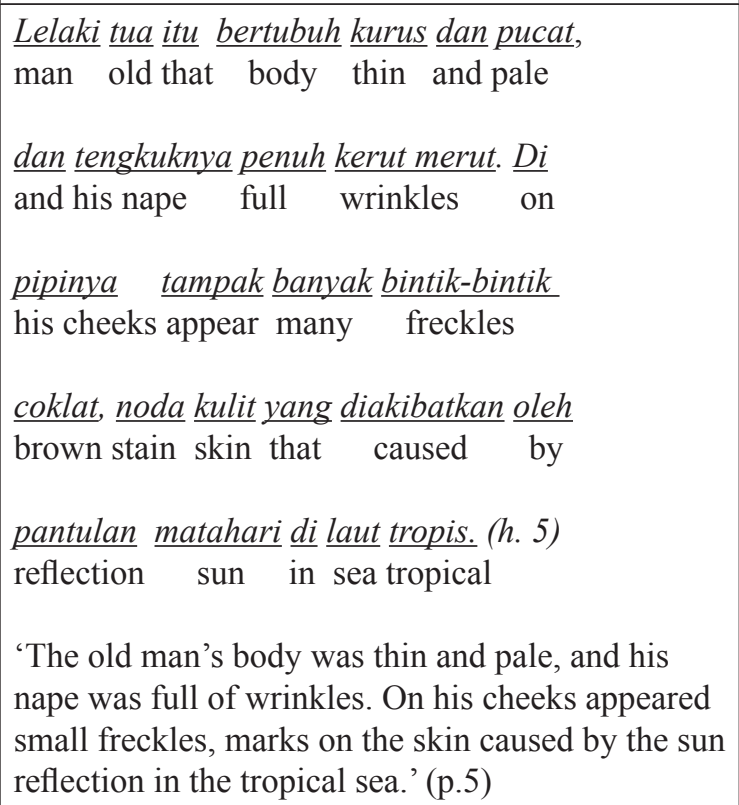 & 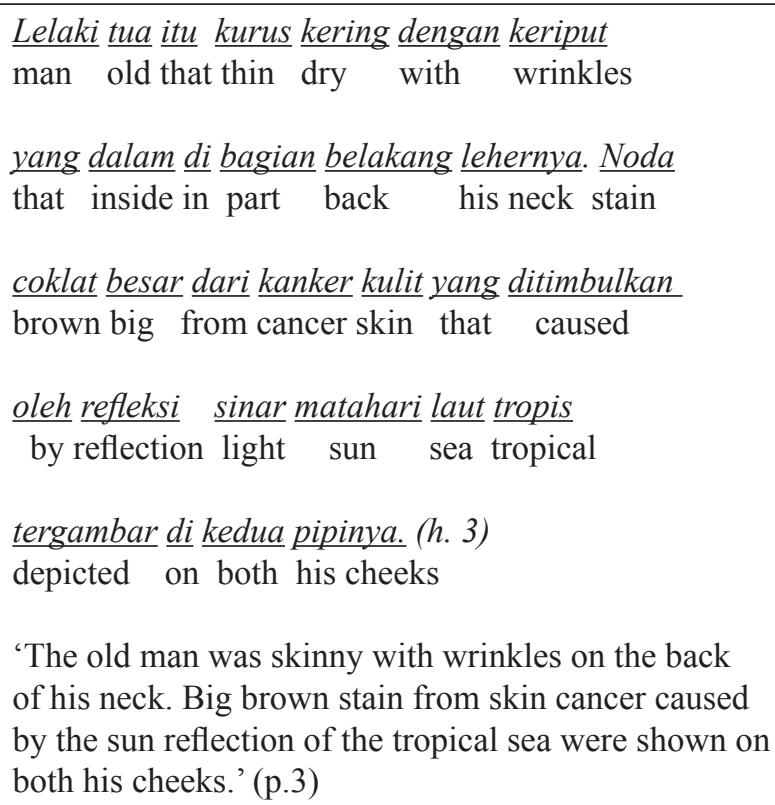 \\
\hline
\end{tabular}




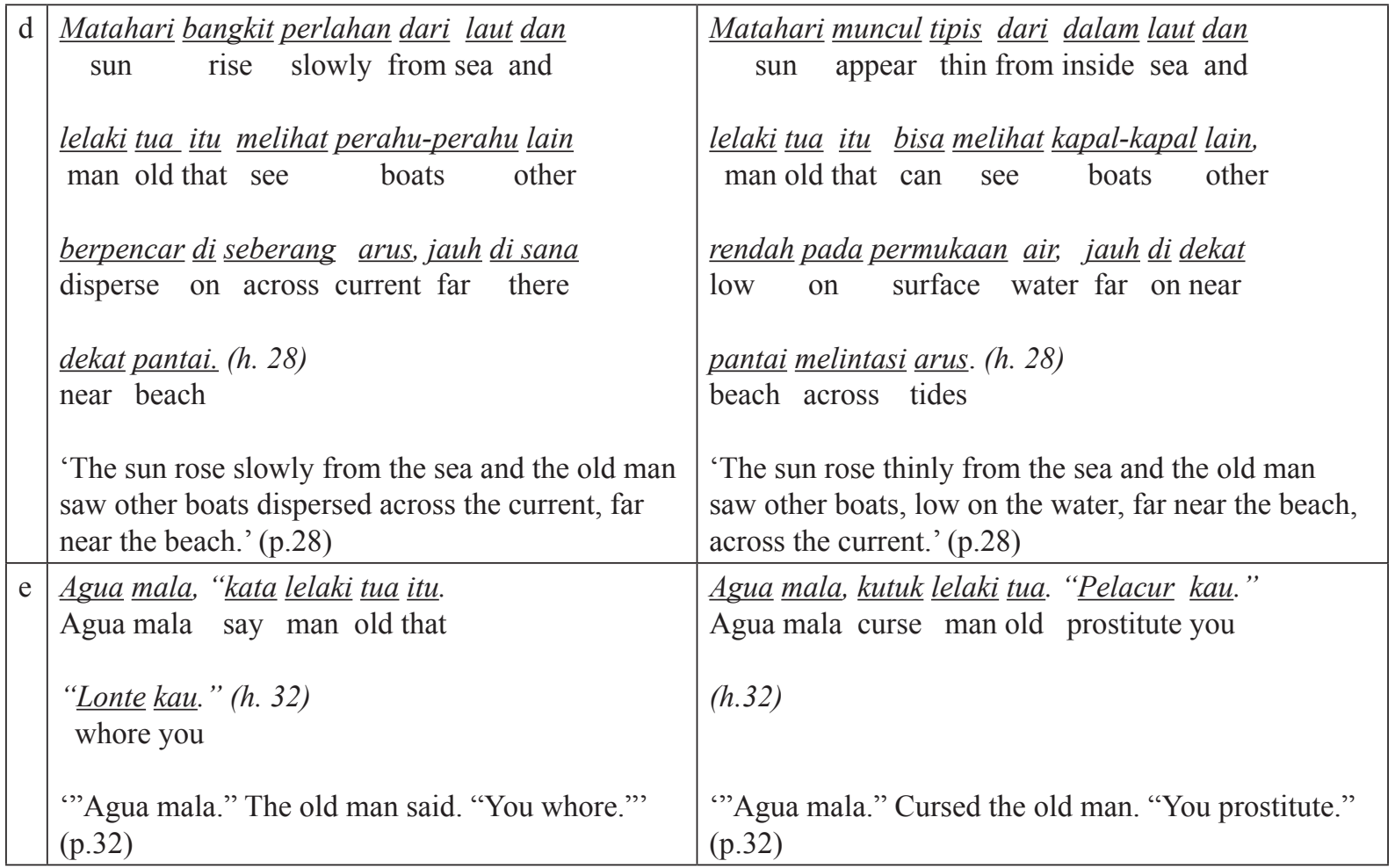

The five excerpts above shows the sentencing of the two translators. In the excerpt (a) SDD maintains poetic expression with the sentence [...] cerah yang tak kenal menyerah '[...] colors were like sea: bright, and never give up' while DVE explains it with detailed description. Poetic expression refers to building up the sentence with rhymed words as if it is a lyrical poetry. In the excerpt (b) SDD chooses the word menatap 'stare', while DVE chooses memandang 'look at'. Both of the words are another form of 'seeing'. Its distinction lies in the object being seen. Menatap 'staring' has more fixed object and a longer time, while memandang 'looking' has an extent width of object. The differences of diction will affect the nuances being built in general. The excerpt (c) explains about physical appearance of an old man. The effect caused by each translation is quite different. SDD describes the freckles on the old man's cheeks is due to the tropical sun, while DVE describes the huge freckles caused by skin cancer. The effect caused by SDD's sentence is normal. It means, it is quite normal for people living in a tropical area and are often exposed to the sun to have freckles on their skin. Meanwhile, DVE translates it with greater influence of meaning to the reader that the old man has huge skin cancer on his face.

Excerpts (d) and (e) also show different diction in conveying something. In the excerpt (d) describing the state of the sunrise, SDD chooses the words bangkit perlahan 'rose slowly', while DVE chooses muncul tipis 'rose thinly'. The diction chosen by both SDD and DVE have different figure of speech. SDD uses personification, while DVE uses analogy. In the excerpt (e) the translation also differs in the expression of swearing. SDD chooses the word lonte 'whore' while DVE chooses pelacur 'prostitute'. Both of the words refer to women who sell themselves. The word lonte in Indonesian culture was popular and commonly used during the $70 \mathrm{~s}$. The word then is rarely used until it is replaced by the word pelacur. This may indicate the identity of the translators because SDD lived in the era when the word lonte was common, while DVE chooses popular word used in her time.

This analysis will be closed with Nida's argument that a satisfying translation on aesthetical literary works requires aesthetical ability of the translator. It requires the sensibilities, the way color management and three-dimensional spatial structure requires aesthetical competence. 


\section{CONCLUSION}

Both of the translations "are not torturing" to be read. They both, thus, have proper readability level. The analysis of the two translations of Lelaki Tua dan Laut results to a number conclusion as follows.

1. SDD's translation shows that meaning is built by finding the suitable and equivalent words to represent the same concept. DVE's translation shows that meaning is built through description and explanation.

2. SDD's translation attempts to maintain poetic expression through rhymed diction. DVE's translation aims more to clarity of meaning.

3. SDD uses more specific meaning words. DVEusesmore commonmeaning word.

Therefore, both of the translations have their own strengths. However, if the readers are after the literary effect, SDD's translation is considered to be more successful.

The analysis of the two translation works indicates that each of the work carries its own vision. As Newman (1988) points out, a work of translation is either near to the source language (word-for-word translation, literal translation, faithful translation, semantic translation) or to the target language (adaptation, free translation, idiomatic translation, communicative translation). SDD is near to the target language by maintaining its literary effect. DVE employs the same method as well by positioning itslef as near as possible to the target-language culture.

\section{REFERENCES}

Álvarez-Recio, Leticia (2016). Spanish chivalric romances in English translation Anthony Munday's Palmendos (1589), Cahiers Élisabéthains: A Journal of English Renaissance Studies, vol.91(1),pp.5-20.

Baker, Mona (2016). The prefigurative politics of translation in place-based movements of protest Subtitling in the Egyptian Revolution, The Translator, vol. 22(1), pp.1-21.

Bassnett, Susan (1993). Comparative Literature: A Critical Introduction, Oxford UK and Cambridge USA: Blackwell.
Bielsa, Esperanza (2015). Media, Culture \& Society, March 2016; vol. 38, 2: pp. 196211.,firstpublishedonDecember 16, 2015.

Chambert-Loir, Hendri (2009). Pendahuluan, in Sadur: Sejarah Terjemahan di Indonesia dan Malaysia, Jakarta: KPG.

Elmarsafy, Ziad and Mustapha Bentaïbi (2015). Translation and the world of the text: on the translation of the word hijab in the Qur'an, in The Translator online p. 210-222. Published online: 30 Nov 2015.

Guy Mboudjeke, Jean- (2016). French in Springfield: a Variationist Analysis of the Translation of First-Person Singular Future Actions in The Quebec and French Dubbings of The Simpson, The Translator, vol.22(1), pp.22-39.

Hamid, Abdul. (1996). Bentuk dan Pilihan Kata" Makalah pada Penataran Guru, Bandung: Tim Pemasyarakatan Bahasa Indonesia.

Izak, Michal, (2016). Nothing left to learn: Translation and the Groundhog Day of Bureaucracy, Management Learning Journal, vol. 47(5), pp. 543-562.

Jacquemond, Richard (2015). Translating social sciences into Arabic today. The case of Pierre Bourdieu, The Translator, vol. 21(2), pp.189209.

Lindsay, Jennifer (2006). Translation and/of/in Performance: New Connection, in Jennifer Lindsay, ed., Between Tongues. Singapore: Singapore University Press.

Sastriani, Siti Hariti (2007). Transformasi Gaya Bahasa dalam Karya Sastra Terjemahan, in Jurnal Humaniora, vo. 19(1), pp. 73-80.

Mohamed Abdelaal, Noureldin and Sabariah Md Rashid (2016). Grammar-Related Semantic Losses in the Translation of the Holy Quran, with Special Reference to Surah Al A'araf (The Heights), SAGE Open, July-September 2016; vol. 6, 3: $2158244016661750 \mathrm{http}: / /$ journals.sagepub.com/doi/full/10.1177/21582 44016661750.

Moriyama, Mikihiro. (2009). "Lahirnya Pembaca Modern: Penerjemahan Cerita-Cerita Eropa ke dalam Bahasa Sunda pada Abad ke-19" in Sadur: Sejarah Terjemahan di Indonesia dan Malaysia. Jakarta: KPG.

Newmark, Peter. (1998). A Text Book of Translation. London: Prentice-Hall. 
Nida, Eugene A. and Charles R. Taber. (1964). The Theory and Practice of Translation, first published in 1982 and a companion work to Toward a Science of Translating. Brill.

Rosidi, Ajip. (2009). Terjemahan Bahasa Sunda" in Sadur: Sejarah Terjemahan di Indonesia dan Malaysia. Jakarta: KPG.

Salam, Aprinus. (tt). Sastra Terjemahan: Beberapa Persoalan in ugm.academia.edu. https://www. academia.edu/1490358/Sastra_Terjemahan.

Scoville, Spencer . (2015). Reconsidering Nahdawi Translation: bringing Pushkin to Palestine, The Translator, vol. 21(2), pp. 223-236.
Sumardjo, Jakob (1988). Perkembangan Terjemahan Sastra Drama Asing Di Indonesia, in Afrizal Malna dkk., ed. Beberapa Pemikiran Tentang Pementasan Naskah Barat Oleh Teater Indonesia (Jakarta: Goethe-Institute Jakarta, 1988), pp. 5-16.

Sumardiono, LP. (2007). Penerjemahan dan Budaya", in http://dion-zydion2i.blogspot.co.id/2009/10/ karya-ilmiah-penerjemahan-dan-budaya.html.

West-Sooby, John (2016). Language and the national allegory: translating Peter Temple's The Broken Shore and Truth into French, The Translator, vol. 22(2), pp.190-206. 